\title{
The socio-economic perspective for post-crisis development of Russia
}

\author{
$V$. Kashirin ${ }^{1, *}, M$. Khalikov ${ }^{1,2}$, and A. Sysoev ${ }^{1}$ \\ ${ }^{1}$ Moscow State University named after M. V. Lomonosov, Economic Faculty, 119991, 1 Leninskie \\ gory, Moscow, Russia \\ ${ }^{2}$ RANH and HS under the President of the Russian Federation, 119571, 82/1 Vernadsky Prospekt, \\ Moscow, Russia
}

\begin{abstract}
The article considers problems of Russian economy through the prism of technology, innovation, and investments. Economists and politicians put the issue of innovative socio-economic development. Further development of R\&D and innovation of modern society directed an increasing share of material and human resources. In the new environment, the intensification of production involves not just improving some individual skills in the organization of the production process, but a sharp reduction in the innovation cycle, accelerate product updates, and applied technologies. The characteristic feature of modern world economic development is the transition of the leading countries to a new type of socio-economic move forward to build an economy based predominantly on the generation, dissemination and use of knowledge. The article considers a wide range of possible transformation of the Russian economic system in modern conditions. It attempts to justify one of the possible approaches to the transformation of the Russian economy in conditions of globalization of world economic relations and transition to a postindustrial economic system of all countries of the world on the path of building a "knowledge economy."
\end{abstract}

\section{The impact of the crisis on the prospects of innovative development of Russia}

When we stress the imperative of further innovative development of our country, we must not forget, in particular, about the immediate practical task of the day, as overcoming the current crisis. The fact that if the periods 1998 and 2008-2009, the Russian economy came out relatively quickly due to the actual recovery of growth in already established sectors, to be more precise - return to its pre-crisis structure, the solution of the current crisis of 20152016 can and should be achieved, primarily, thanks to a breakthrough in the most advanced fields that use innovation achievements. And here an appeal to the international experience shows how to date, our country is late in making and implementing decisions that may lead to innovative "breakthrough".

\footnotetext{
* Corresponding author: kavava@list.ru
} 
The problem is that the global crisis that began in 2007-2008 showed that the most effective against him were capable of in the first place precisely the countries with advanced, diversified manufacturing industries (and regardless of their social system), continuously use for its development of the latest scientific and technological achievements (innovations). To these primarily include China, and in Europe - Germany. It is important to note that these same countries are the top three exporters, with China now for several years occupied by the volume of its exports first in the world [1].

You can make an informed conclusion that to ensure stable, sustainable growth of the national economy in the long term, however, worthy of its place in world economy is possible primarily on the basis of innovative development of the it manufacturing industries. Innovative growth industries will create opportunities and conditions for sustainable growth and the entire national economy.

So, in industrialized countries to date in scientific theory and practice formed the following sectoral division of the national economies:

- industry mining and primary processing of raw materials;

- traditional heavy industry, usually in material - and labour-intensive industry;

- high-tech industry, characterized by relatively low consumption of materials and complexity, but a very high proportion of $\mathrm{R} \& \mathrm{~d}$ expenditure in value added;

- industry services (software development, system integration, consulting, education, etc.).

In the countries with innovative economy based on knowledge from-industry structure of the economy changes in the direction of constant increase of the share of the latter two groups of industries in the structure of the national economy. It is very essential that the specificity of technologies of these two groups is that they are based on the wide use of results of intellectual work, i.e. new knowledge.

Innovative growth - with continued up to the present day instability of a world economy as a whole - cannot be achieved on the basis of, say, the previously used extensive factors, and can be secured in the innovation area, allowing you to switch to a more efficient path of economic growth with the application of intensive factors. So once again it should be emphasized that innovation is not a fad, not just form the "face" of the national economy in the world economy (although in some degree it may be true), but, above all, creating a solid Foundation for sustainable growth for the future.

Before you answer the above question about the factors influencing the competitiveness of the national economy, let's ask another: what is meant by competitiveness in relation to the macroeconomic scale? First of all, the possession of certain competitive advantages in comparison with other regions of the world economy. Competitive advantages of the national economy include:

First, achieved in particular national economies the standard of living and wages, and empowerment of workers, especially in areas that determine the development of scientific and technical progress.

In our days, for these issues, especially true innovation, in particular, the field of information technology. However - and this must be stressed - do not forget about the leading industries of the real sector, particularly manufacturing industry and the engineering and machine tool industry, without which, ultimately, can be no mass emergence of innovative products, rising productivity based on technical progress. Priorities of industrial production are manifested, for example, in the rapid development in recent decades of high-tech enterprises of the pharmaceutical and medical industries, which differ in nearly all developed countries, as well as some of the most rapidly developing economies in the third world (especially India).

In this regard, speaking about our country, it should be noted that, unfortunately, our competitive production is still concentrated mainly in the commodities and mining sectors. 
Only by changing the structure of the economy, we will be able to solve major problems in the field of security and social development, to create modern jobs and increase the quality and living standards of millions of our people.

Of course, we have successful businesses in industry, agriculture, small and medium business. The main objective is that the number of such companies has grown faster and in larger number of industries. To achieve this purpose should be sent to national programs of import substitution and export support, technological renewal of production and professional training.

\section{Possible measures to bring Russia to a trajectory of long-term sustainable growth. The role of the "may decrees" the President of the Russian Federation in improving the socio-economic situation}

To date, the direct consequences of the still ongoing crisis of the Russian economy and society will be felt at least until early 2017. It became clear, in particular, the results of last at the end of August 2016 the meeting, the Chairman of the government of the Russian Federation Dmitry Medvedev, during which it was decided to hold the second, the longpromised pensions will not "regular format" and in the form of lump sum payments to pensioners in the amount of 5 thousand rubles. In this case, this payment should occur (and later) did not fall and even in December 2016 and January, 2017. Later this decision was issued in the form of a Federal law passed by the newly elected State Duma.

It is clear that the decision to move the payment to pensioners for the next year was not a good life and is directly linked to the crisis outcomes. In the following months at high level Russian authorities have repeatedly heard statements about the difficult situation in the field of Finance.

So, even in the summer, Russian Finance Minister Anton Siluanov announced forecast that by 2016 the reduction of Federal budget revenues could reach about 1.5 trillion rubles, which again means a direct confirmation by the ongoing Russian financial crisis. A little later, at the beginning of October 2016 at the next meeting of the government of the Russian Federation Prime Minister Dmitry Medvedev said that the average for the current year the price of Russian oil was significantly lower than that budgeted. "Accordingly, less revenue from exports," - said the head of government.

The head of the Russian government said the already calculated data for a year. "Slightly better situation income for a number of other positions - he said, - but it only partially covers the shortfall of funds from oil exports. In the result the budget revenues is reduced by 370 billion roubles." [5, p. 3].

It is clear that these budget losses have impact on the social development of the country. About the effectiveness of the actual fiscal policy more will be discussed below; here we would like to concentrate on the social component of transition to innovative type of development. The fact that in modern Russia, according to the remark of Professor Fields Savchenko from the Institute of Economics of the Russian Academy of Sciences, the social sphere is considered rather "as a reserve of economy of budgetary funds" [6, p.142].

Meanwhile, it is clear that the imperative transition to innovative type of development requires as an imperative to reduce population in district traits and below the poverty line. This is generally one of the important conditions for ensuring innovative growth, as people in poverty or close to it may not be innovative in any of the areas of economic and overall social activities.

This, in particular, relates to the possibilities of productive labor. Thus, according to the rector of the Financial University under the government of the Russian Federation Mikhail 
Eskindarov, the productivity of those employed in the Russian economy today is still on average 3-4 times lower than in developed countries [7, p.11].

Thus, the relationship between high performance and capabilities of the modern worker to enjoy the achievements of social development becomes more apparent and immediate.

This proves modern foreign practice of developed countries, where the social sector does not save. Thus, according to Rosstat, in 2012 public expenditure on education and health in our country, in aggregate, amounted to 7.8 percent of GDP, while, for example, in Finland $13.5 \%$, U.S. $13.8 \%$, Germany $14.1 \%$, in Austria and Great Britain $14.4 \%$, in Norway $-14.9 \%$, France $15.2 \%$, and in Denmark - as much as 18.4 percent.

It should be noted that most of the above countries (except Austria and Finland), member of NATO and forced - on the good will or under pressure from the US - to bring constant and often considerable military spending. However, the overall effectiveness of their fiscal policy is that the key spheres of modern society - healthcare and education funds in these countries is lacking.

In this regard, achieving acceptable recognized elevation in social development of the Russian Federation population appears to be the most important task for the sustainable long-term growth.

The system of measures which, in our opinion, must be taken to ensure that such a withdrawal, must include the execution of the may decrees of President Vladimir Putin.

Recall that during the election campaign for the presidential election in 2012, Vladimir Putin presented his program in seven articles published in the Central print media.

May 7, 2012, immediately after the inauguration of the Russian President, Vladimir Putin signed a number of decrees, which reflected, in General, expressed in the aforementioned articles of the basic provisions and which was formulated long-term objectives in the economic, demographic and social policy, healthcare, education and science, providing citizens with affordable housing.

So, signed the decrees, called the "may decrees":

- "On long-term state economic policy";

- "On measures on realization of demographic policy of the Russian Federation";

- "On measures to implement the foreign policy of the Russian Federation";

- "On further improvement of military service in the Russian Federation";

- "On implementation of plans (programs) of construction and development of the Armed

Forces of the Russian Federation, other troops, military formations and bodies and upgrade oboronno-an industrial complex";

- "On ensuring interethnic consent";

- "About the basic directions of perfection of system of public administration";

- "On measures to ensure Russian citizens affordable and comfortable housing and improve the quality of housing and communal services";

- "On measures on realization of state policy in education and science";

- "On improving state policy in healthcare";

- "On measures to implement state social policy".

As you can see, signed the decrees first, cover almost all major areas of state-political (including foreign policy) and socio-economic life of the country, and secondly, can be considered as specific possible direction of socio-economic modernization of Russia.

Further activities of the Government of the Russian Federation and public authorities at the regional level largely were developed with the ultimate goal of implementation of the may decrees. They simultaneously began to play the role of a effectiveness indicator of socio-economic policy at the Federal and regional levels.

The implementation of "may decrees" had in the period of accession of the Russian economy in full-blown crisis; at the same time the country has experienced the impact of 
unilateral sanctions by Western States. However, in may 2016 Vladimir Putin demanded the unconditional performance of "may decrees" regardless of external conditions.

"Four years ago in the famous "may decrees" were designated purpose in the economy, social sphere, demography, science, education, and other areas. We took then a great responsibility to citizens and should operate without reference to the complexity and external constraints," - said the head of state at a meeting on the implementation of "may decrees".

At the meeting, in particular, stated that the Cabinet of Ministers "performed 88 percent of the orders for the "may decrees" of the President." Seems to have been done, however, the President stressed that "to evaluate the results of this work have not by the number taken from control orders or volume-written reports - we are able to do and learned." Putin expressed the belief that "people should feel real change for the better must feel that, for example, it is easier to create a business, to have a child in kindergarten, move to new, more comfortable housing, to quality health care". According to the President, "this is the basic things that determine the well-being of millions of Russian families".

Thus, we can conclude that measures to accelerate the development of the social sphere and, putting the question more broadly, improving the quality of life of Russians be the most important component of the overall set of measures to enter the innovative way of development.

Later this was once again confirmed by Prime Minister Dmitry Medvedev in November 2016, after referral of the draft Federal budget for 2017 and for the period 2017-2019 years to the State Duma. According to his statement, the budget priorities for the 2017-2019 years, are the fulfillment of social obligations and of the may presidential decrees. [8, p.5] the Russian leadership does not hide that the task is not easy. So, in order to perform that part of the may decrees, which seeks to improve wages for some categories of workers (the so-called "payroll decrees"), the government, in particular, has made the decision on increase in deductions in Fund of obligatory medical insurance to 5.9 percent starting in 2019.

For its part, serious measures will be regions. In particular, in the next 3 years, payroll funds will grow to 800 billion rubles.

In General, President Vladimir Putin stated that in a number of areas in Russia managed to achieve its targets. "The figures show a decline in infant and maternal mortality. This objective data, the President said. - We have reached a historical minimum historical maximum life expectancy in the country. Reduced mortality from cardiovascular and other diseases significantly increased the availability of high-tech operations".

However, the Russian President believes that the claims of citizens to the quality of health care is justified. "However, citizens often have a valid claim to health care, the President said. - People how professional, well-provided with medical assistance. I should say that qualified doctors, especially specialists, paramedics in the village often lack. Particularly acute problem is felt in small towns, remote areas". According to the head of the state, today this problem comes to the fore.

In General, President Vladimir Putin has particularly affected regional component, social policy, stressing that he considers it essential that the objectives of the "may decrees", was carried out throughout the Russian Federation.

"It is necessary to improve the quality of life of people and in large and small cities and in the countryside. Special attention should be paid to hard-to-reach, remote areas, including Siberia and the far East", - the President set the task. In his view, "there must be further efforts for the development of health, transport infrastructure, housing construction and modernization of housing and communal services".

In this last respect, it should be said about the situation in the construction industry. According to the forecast of the Ministry of construction of Russia, in 2016 the share of 
innovative goods, services and performed works should reach 20 percent of the total. [9, p. A1] we Can say that the industry is not in the worst position from the point of view of innovation development; in particular, today in the construction of buildings in Russia use a variety of modern technologies. However, in the field of industrial construction increasingly uses elements of steel structures, and here we should pay attention to the fact that the Russian practice of construction of buildings and structures out of steel is still significantly inferior to foreign, including European.

Returning to the problems of social development, we should say that all of the above and many other measures of socio-economic nature are undertaken with the aim of enhancing creativity running and encourage "innovation impact" enforcing pillars of sustainable development.

And this idea is further highlighted in the Message of President RF to the Federal Assembly, which Vladimir Putin spoke on 1 December 2016. In it, in particular, V. Putin noted that "the meaning of the whole of our policy is investing in people, increasing the human capital as the main wealth of Russia. Therefore, our focus is on supporting traditional values and the family, population programs, improving the environment, human health, development of education and culture" [10, c.2] In addressing all of these issues, the importance of interdisciplinary approach in scientific research concerning social development, drastic increases.

\section{A systematic approach to forecasting post-crisis development of Russia}

In addition to measures of socio-economic nature, to ensure sustainable development remains an important set of measures of organizational, economic and legal nature. Moreover, it can be stated that currently, the need for comprehensive application of such measures is of particular relevance.

What measures can be discussed? In our opinion, these include:

1. Access to cheap investment resources. The availability of flexible, easy conditions of the loan for the investor.

2. Creation of comfortable conditions for opening new businesses operating in innovative directions. The introduction of tax credits within the total volume of capital investments undertaken by such enterprises.

3. Enhancing the capacity of banks in lending to the economy, including small and medium business, implementation of targeted policies to reduce the cost of loans in General.

4. Simplification of procedure of selection of promising investment projects and granting state guarantees.

5. A reasonable reduction of import and

the return of the Russian domestic market to domestic producers. The continuation of the policy of competitive import substitution in industry and agriculture.

6. Support of companies implementing the best available techniques, environmentally friendly and safe.

7. Stop the use of outdated equipment and "dirty" technologies, the revaluation of all assets. The increased tax burden on outdated production funds.

8. Expanding the involvement of private capital and resources in investing in infrastructure projects.

Recall that in 2008 was adopted the "Concept of long-term socio-economic development of the Russian Federation for the period till 2020", and in 2011 - "the Strategy of innovative development of the Russian Federation for the period till 2020". In our view, no urgent filling of these documents the real economic content, including with respect to 
clearly defined objectives relating to the parameters of economic growth, it is difficult to count the real impact of any strategic concept.

And here still having issues, still are not getting the proper permission. For example, in the development of scenario conditions and main forecast parameters of socio-economic development of Russia for 2016 - 2018, Ministry of economic development laid in the calculations of the basic installation that the indexation of tariffs of natural monopolies will be made not higher than the level of projected inflation of previous periods.

However, such indexation is only formally able to contain inflationary trends, because to use a flawed economic model to "adjust" the rates under the rate of inflation, asking her, thus another round. While all loved by many representatives of our so-called "elite" developed Western countries for decades how to act just the opposite: the state regulates all tariffs related to natural monopolies and public utilities, with the aim of curbing inflation.

According to the Federal Antimonopoly service (FAS), in Russia should appear national plan for the development of competition. According to the same information, the need for training in the near future such a plan approved by Prime Minister Dmitry Medvedev. [11, p.2]

Under this plan, each sector in the Russian economy will have to provide their own industrial development program competition. It is hoped that the role of interdisciplinary research in the preparation of such programs will objectively increase.

Meanwhile, among the other the question arises about forecasting economic growth in post-crisis Russia. Thus, the available projections of the European Commission (the main Executive body of the European Union - ed.). According to the same forecasts, the growth can be expected only in 2017. About the same forecast gives the international monetary Fund (IMF).

But how can this growth? If the above predictions are confirmed, then next year the Russian economy can show growth of 1 percent. For its part, the world Bank experts the report "Global economic prospects" claim that in 2017, Russian economy will emerge from recession and start to grow slowly is expected to increase GDP by 1.3 percent. If that happens, then the next one, 2018, the Russians can count on GDP growth of 1.5 percent.

Meanwhile, Dean of the economic faculty of Moscow state University. M. V. Lomonosov Professor Alexander Auzan very appropriate recalls in this connection that in order for people to feel improvement of life, we need economic growth at 3-4 percent per year [12, p.16].

This idea was reflected in the Message of President RF to the Federal Assembly, delivered on 1 December 2016. Vladimir Putin instructed the Government of the Russian Federation with the participation of leading business associations to develop a substantive action plan 2025, the implementation of which should enable at the turn of 2019-2020 to get on the pace of economic growth above the world. [13, p.3] otherwise, we will have a situation of economic stagnation.

In turn, to provide such economic growth without a radical turning to innovative sources of growth virtually impossible; therefore, the problem of innovative development is now becoming crucial for Russia.

\section{References}

1. WTO, Annual report (WTO, Geneva, 2013)

2. Russian Newspaper, 109 (2016)

3. Kommersant-Review: Education, 173 (2016)

4. Russian Newspaper, 263 (2016)

5. Russian Newspaper, 227 (2016) 
6. P. Savchenko, Essays on the socio-economic System of Russia: the human factor in development (INFRA-M, Moscow, 2016)

7. Russian Newspaper, 234 (2016)

8. Statements, 215 (2016)

9. Russian Newspaper, 109 (2016)

10. Russian Newspaper, 274 (2016)

11. Russian Newspaper, 221 (2016)

12. A and F, 48 (2016)

13. Russian Newspaper, 274 (2016) 